\title{
Exchange Rate Pass-through in Russia
}

by

\section{Yuri Ponomarev}

Research fellow at the Institute of Applied Economic Research of the Russian Presidential Academy of National Economy and Public administration (RANEPA); research fellow at the Gaidar Institute for Economic Policy (Moscow)

(ponomarev@iet.ru)

\section{Pavel Trunin}

Ph.D. in economics, Head of the Macroeconomics and Finance Division at Gaidar Institute; Leading Research Fellow at RANEPA's Center for Central Banking Studies

\section{Alexei Uluykaev}

Doctor of Economics, Minister of Economic Development of the Russian Federation.

March 2014 


\begin{abstract}
The article provides estimates of short-run and medium-run exchange rate pass-through into domestic prices in Russia during the period of 2000-2012 using vector error correction model. Exchange rate pass-through asymmetry estimates, its assessments on different sub-periods and exchange rate volatility effect on pass-through are also provided.
\end{abstract}

Keywords: exchange rate pass-through, asymmetry of exchange rate pass-through, exchange rate volatility, inflation, monetary policy, vector error correction model.

JEL Classification: C32, E31, E52, F31, F41. 


\section{Exchange Rate Pass-through in Russia}

Active integration of global capital markets and mounting volumes of international trade have increased the relevance of studying the extent and nature of national currency exchange rate fluctuations effect on domestic prices, the so-called exchange rate pass-through effect (ERPT). ERPT shows the extent of changes (driven by various mechanisms) in the national currency exchange rate on domestic prices. It's important to study ERPT, for it should be considered in setting up economic policy, because a strong pass-through effect renders an open economy more prone to shocks in global markets.

\section{Pass-through effect in literature}

The economic literature distinguishes a few core channels - direct, indirect, and foreign direct investment (FDI) - of exchange rate fluctuations impact on domestic prices.

The direct channel is closely associated with changes in domestic prices of imported goods expressed in national currency (Obstfeld, Rogoff, 2001).

The indirect channel relies on the possibility of cross-substitution between imported and domestic goods in both the domestic market ("domestic substitution") and foreign markets ("foreign substitution") of trade partners. The cross-substitution may be triggered by changes in relative prices of imported and domestic goods driven by fluctuations of exchange rates (Obstfeld, 2001; Engel, 2002 et al.).A depreciation of the national currency will, on the one hand, rise domestic demand for domestic goods (“domestic substitution"), because national currency denominated prices of imported goods go up, and, on the other hand, boost foreign demand for domestic goods ("foreign substitution"), because their relative value declines. This will bolster up domestic production, wages, and domestic prices. 
The channel of exchange rate impact on domestic prices through foreign direct investment draws upon the effect associated with relocation of foreign firms' manufacturing facilities and respective changes in FDI channels. In case of persistent depreciation of the national currency in any country foreign exporters would find it more beneficial to relocate their manufacturing facilities (or set up new ones) to this country, thereby increasing its domestic output, driving up the labor demand, raising wages and therefore domestic prices.

According to a basic concept of cross-country price ratios - purchasing power parity $(\mathrm{PPP})^{1}-$ exchange rate fluctuations pass-through into domestic prices must be complete, i.e. exchange rate elasticity of domestic price level must be equal to 1 (or $100 \%$ ). In many cases, however, the assumptions underlying the PPP concept fail to be met de facto (e.g. because of transaction costs, etc.), which may result in an incomplete pass-through effect, as well as differences in its magnitude and peculiarities governed by features of national economies.

This fact can be explained by microeconomic effects governed by special features of the commodities market structure in various countries and firms' behavior. Therefore, differences in ERPT between various countries can be determined by:

- transportation costs which increase the value of imported goods and flatten the effect of exchange rate fluctuations on aggregate price indices (Obstfeld, Rogoff, 2000);

- differences in the structure of consumption (in which the share of imported goods may vary; McCallum, Nelson, 2000) and services (consumers pay for nontradable services etc., therefore the price share of goods affected by exchange rate fluctuations may be small while the pass-through effect incomplete; Bacchetta, Wincoop, 2003);

- price discrimination (Bacchetta, Wincoop, 2003);

- possible discrimination of various markets (pricing-to-market; Knetter, 1994) - the value of the pass-through effect will vary in various markets;

\footnotetext{
${ }^{1}$ See Drobyshevskiy, Sinelnikov, Trunin, 2011.
} 
- differences in firms' pricing models - ERPT is stronger when a price level and output volume are selected to maximize total profit (Phillips, 1988), whereas it gets weaker when the goal is to maximize the market share (Ohno, 1990);

- currency of pricing - a currency in which goods are priced - (Gopinath et al., 2007), and firms' currency selection decisions (Devereux et al., 2004) (countries whose national currency is less stable would have more imported goods priced in foreign currency);

- the extent of cross-substitution between intermediate domestic and imported goods - driven by exchange rate fluctuations, intermediate imported products are substituted with domestic ones (Obstfeld, 2001);

- the degree of market segmentation (Goldberg, Knetter, 1996) - ERPT is weaker in more segmented industries in which firms have more opportunities for consumers discrimination;

- expectations of future exchange rate dynamics (Froot, Klemperer, 1989).

Macroeconomic situation in a country plays a significant role in estimating the pass-through effect value. For example, a highly volatile exchange rate makes it less beneficial for importers, resulting in a weaker ERPT (Engel, Rogers, 1998). An overall steady demand for goods also may impact the magnitude of the effect - frequent changes of the demand make it less beneficial for importers to change prices, resulting in a weaker ERPT (Mann, 1986).

According to the Taylor's conclusions the higher is the level, duration and volatility of inflation, the stronger is the pass-through effect (Taylor, 2000). The authors of other papers confirm this relationship, showing that countries with low inflation are facing a mild ERPT, whereas it gets stronger in most of the countries with traditionally high inflation (Engel, 2002; Calvo, Reinhart, 2002). It has been revealed that the pass-through effect gets weaker as the economy becomes more stable (Gagnon, Ihrig, 2004; McCarthy, 2000). Additionally, a few papers suggest that disinflation is the key stabilizing factor that flattens the pass-through effect (Takhtamanova, 2010).

Asymmetric price rigidity may be another reason for incomplete and variable ERPT (Dolado et al., 2005): goods` prices demonstrate different responses to changes 
in their manufacturing costs, being less responsive to reduction and more responsive to rise in manufacturing costs. Therefore, changes in the exchange rate which drive up or down the value of intermediate goods will lead to changes in manufacturing costs of final goods, thereby influencing in different ways the dynamics of final prices, i.e. the pass-through effect may vary under appreciation and depreciation of national currency (Cozmânca, Manea, 2010). Additionally, a few papers demonstrate that the higher is inflation in a country, the bigger is ERPT asymmetry (Flodén, Wilander, 2006).

There are many studies which are dedicated to empirical estimation of the passthrough effect in various countries. According to the estimates obtained for developing countries, ERPT may vary within a wide range of 30-40\% in a month (Stavrev, 2003) to $30 \%$ quarterly, and 50-70\% over two-three quarters (Oomes, Ohnsorge, 2005).

\section{Exchange rate pass-through effect in Russia: estimation}

A comparative analysis of different approaches to empirical estimation of the pass-through effect has led to the following conclusions. First, the following key research methods have been distinguished:

- panel data models (Bailliu, Fujii, 2004; Ball et al., 1988 et al.);

- estimation of simultaneous equations systems (Salitsky, 2010);

- vector autoregression models or vector error correction models (Beirne, Bijsterbosch, 2009; Bitans, 2004 et al.).

Second, the models set up in the foregoing papers allow to obtain ERPT estimates for different countries as well as for each country in particular.

Third, the empirical analysis results show that ERPT may vary widely as determined by the economy's structural features, as well as other parameters.

Fourth, one can state theoretical hypotheses about the following key determinants of ERPT in the short and medium-term periods:

- national currency exchange rate; 
- monetary base which reflects monetary policy's impact on ERPT structural features;

- oil price level as essential factor of Russia's trade balance, that in turn has an effect on ruble exchange rate dynamics;

- economic output indicator, an important factor in the exchange rate dynamics which therefore can have impact on ERPT.

To estimate ERPT it is expedient to use a vector autoregression model or (in case of cointegration in the obtained data) a vector error correction model which analyzes the dynamics of Russia's economic indicators and allows typical structural changes in ERPT to be traced. Each of the studied indicators' dependence on the total set of all endogenous and exogenous variables in question, as well as their lagged values, is constructed as part of the model. This structure of the model helps to resolve the

endogeneity problem (this is a key advantage of the model over the other models as part of this study), because it allows for interaction between all endogenous variables, as well as it estimates the magnitude of the effects under consideration. Additionally, by virtue of taking in account cointegration relations vector error correction model helps trace long-term interactions between the variables under consideration and draw conclusions about the examined interactions not only in the short but also long-term period. Table 1 presents the characteristics of the variables used for estimation.

Table 1

Data description

\begin{tabular}{|c|r|r|}
\hline $\begin{array}{c}\text { Indicator's } \\
\text { designation }\end{array}$ & $\begin{array}{r}\text { Source (number of } \\
\text { observations) }\end{array}$ & $\begin{array}{r}\text { Description } \\
\text { (as percentage of base period - January 2000) }\end{array}$ \\
\hline$C P I_{t}$ & $\begin{array}{r}\text { Federal State Statistics } \\
\text { Service (FSSS) (151) }\end{array}$ & Consumer price index \\
\hline$B C P I_{t}$ & $\begin{array}{r}\text { (Dementyev, } \\
\text { Bessonov, 2012) } \\
\text { FSSS (151) }\end{array}$ & Fore consumer price index \\
\hline$F C P I_{t}$ & FSSS (151) & Non-food products consumer price index \\
\hline$N G P I_{t}$ & FSSS, Central Bank & Producer price index \\
\hline$P P I_{t}$ & FSSS (151) & Nominal effective exchange rate of the ruble \\
\hline$N E E R_{t}$ & BIS* (151) & Ruble-dollar exchange rate \\
\hline$U S D E R_{t}$ & Central Bank (151) & Ruble-euro exchange rate \\
\hline$E U R E R_{t}$ & Central Bank (151)
\end{tabular}




\begin{tabular}{|c|r|r|}
\hline$M 2_{t}$ & Central Bank (151) & M2 monetary aggregate \\
\hline Oilpr $_{t}$ & $\begin{array}{r}\text { Platts Information } \\
\text { Agency** }(151)\end{array}$ & Price of Urals oil brand \\
\hline $\operatorname{Prod}_{t}$ & FSSS (151) & $\begin{array}{r}\text { Production index by core type of economic activities, } \\
\text { output index of the core industries of the economy }\end{array}$ \\
\hline
\end{tabular}

Notes. * Bank for International Settlements.

** For more details see www.platts.com/AboutPlattsHome.

Data source: authors' estimates.

Dickey-Fuller and Phillips-Perron tests are used to test for stationarity of time series and define the order of integration of the time series in question. On the whole the test results agree with each other for all of the time series in question, except for $B C P I_{t}$ and $N G P I_{t}$ indicators which demonstrate different test results: the Dickey-Fuller test allows the unit root hypothesis to be rejected in certain cases, while the PhillipsPerron test demonstrates opposite results for a couple of specifications. To maintain consistency of the estimation method to be subsequently used, we consider the foregoing time series as first order integrated time series. Therefore, cointegration relations may exist in the presence of all these variables.

A Johansen test is used to test for cointegration. The test results show that the data in question contain several (the quantity depends on the test specification) cointegration relationships, and the vector error correction model deals with this problem.

The specification of the vector error correction model to be used for estimation is as follows:

$$
\Delta Y_{t}=\Pi_{0}+\sum_{i=1}^{n} \Pi_{1 i} \Delta Y_{t-i}+\Pi_{2} \Delta X_{t}+\Pi_{3} \varepsilon_{t-1}+\xi_{t},
$$

where $Y_{t}$ is endogenous variables vector $\left(p_{t}\right.$, ExchRate $\left._{t}, M 2_{t}, \operatorname{Prod}_{t}\right) ; X_{t}$ is exogenous variables vector $\left(O i l p r_{t}\right) ; \xi_{t}$ is random error vector; $\Pi_{0}, \Pi_{1}, \Pi_{2}, \Pi_{3}$ are coefficient matrices.

All variables are represented in logarithms, and $\varepsilon_{t-1}$ denotes lagged residuals of cointegration relationship. In case of more than one cointegration relationships the 
estimated model specification is supplemented with vectors of residuals for detected extra cointegration relationships.

Hence for each of three variables reflecting the ruble exchange rate indicator a model is estimated using each of the five dependent variables corresponding to different price indices.

The Oilpr $_{t}$ variable is considered as exogenous when the models are estimated, because oil price level is determined on the global market and cannot be influenced by the other variables in question. The other variables were considered as endogenous.

Observations corresponding to appreciation and depreciation of the exchange rate are selected from the total sample to assessexchange rate pass-through asymmetry. ExchRate $_{t}^{+}$denotes a series of positive partial sums corresponding to the periods of ruble appreciation, while ExchRate $_{t}^{-}$denotes a series of negative partial sums corresponding to the periods of ruble depreciation. Such expressions for these time series can be written as follows: ExchRate $_{t}^{+}=\sum_{i=1}^{t} \Delta$ ExchRate $_{i}^{+}=$ $\sum_{i=1}^{t} \max \left(\Delta\right.$ ExchRate $\left._{i}, 0\right) \quad$ and $\quad$ ExchRate $_{t}^{-}=\sum_{i=1}^{t} \Delta$ ExchRate $_{i}^{-}=$ $\sum_{i=1}^{t} \min \left(\Delta\right.$ ExchRate $\left._{i}, 0\right)$.

The model (1) can therefore be written as follows:

$$
\Delta \widetilde{Y}_{t}=\Pi_{0}+\sum_{i=1}^{n} \Pi_{1 i} \Delta \tilde{Y}_{t-i}+\Pi_{2} \Delta X_{t}+\Pi_{3} \varepsilon_{t-1}+\xi_{t},
$$

where $\widetilde{Y}_{t}$ denotes endogenous variables vector $\left(p_{t}\right.$, ExchRate $_{t}^{+}$, ExchRate $_{t}^{-}$, $\left.M 2_{t}, \operatorname{Prod}_{t}\right) ; X_{t}$ denotes exogenous variables vector $\left(O i l p r_{t}\right) ; \xi_{t}$ is random error vector; $\Pi_{0}, \Pi_{1}, \Pi_{2}, \Pi_{3}$ are coefficient matrices. This model specification allows ERPT asymmetry to be considered not only in the short but also long-term period.

ERPT may change driven by the Russian economy's specific features as well as changes in the Central Bank's policy. For example, changes in the Bank of Russia's policy, in particular easing interventions in the foreign exchange market, may impact ERPT structural features. To be able to detect such changes, we broke down the sample in question into two sub-periods. The first sub-sample corresponds to the period of January 2000 to December 2008, while the second one to the period of January 2009 
to July 2012. It is noteworthy that the Central Bank of Russia changed its foreign exchange policy almost at the time when the Russian economy was hit by the global economic crisis. Therefore, changes in ERPT in that and later periods might be associated with that impact. Zivot-Andrews tests (Zivot, Andrews, 2002) are performed to detect the exact moment of structural change in the dynamics of each indicator, because amid economic turbulence it's hard to talk about equal in time impact of the crisis on the dynamics of varoius indicators reflecting price levels. The Zivot-Andrews test allows the date of structural change (considered endogenous) in the dynamics of any given variable to be determined.

The approach for estimating structural changes in ERPT involves performing calculations (estimating the model (1)) in each of the specified sub-periods and comparing obtained ERPT estimates.

The model (3) specification is estimated to detect the impact of exchange rate volatility on ERPT, which can be written as follows:

$$
\Delta \breve{Y}_{t}=\Pi_{0}+\sum_{i=1}^{n} \Pi_{1 i} \Delta \breve{Y}_{t-i}+\Pi_{2} \Delta X_{t}+\Pi_{3} \varepsilon_{t-1}+\xi_{t}
$$

where $\breve{Y}_{t}$ is endogenous variables vector $\left(p_{t}\right.$, ExchRate $_{t}$, Prod $_{t}$, ExchRate $\left._{-} e_{t}\right)$; ExchRatess $e_{t}$ is squared deviation vector for exchange rate indicator; $X_{t}$ is exogenous variables vector $\left(O i l p r_{t}\right) ; \xi_{t}$ is random error vector; $\Pi_{0}, \Pi_{1}, \Pi_{2}, \Pi_{3}$ are coefficient matrices.

Comparing the coefficients obtained from estimation of the model (3) and model (1) allows to make conclusions about the extent to which exchange rate volatility impacts ERPT.

\section{Estimation results}

The Johansen test results show several cointegration relationships depending on the used base test-statistics ${ }^{2}$. In case of different number of cointegration relationships any given specification of the vector error correction model is selected on the basis of

\footnotetext{
${ }^{2}$ Trace or Maximum Eigenvalue statistics.
} 
information criteria, of which preference was given to the Schwarz criterion. The maximum number of cointegration relationships is three for all model specifications. To ensure comparability of the obtained estimates three cointegration relationships are used in all model specifications.

Note that different number of lagged variables in the above stated models can be selected for different price indices and exchange rate variables. Therefore, equal number of lags is required in the model for the purpose of estimates comparability for different specifications. Different criteria (as part of a test for optimal lag number - lag length criteria test) are used to select an optimal number of lags, of which preference was given to the information (Schwarz) criterion. The test results show that the optimal number of lags is 1 .

Table 2 presents the results obtained from estimation of ERPT as part of the model (1). The presented ERPT estimates for one month is the price level short-term elasticity to exchange rate. The presented estimates of cumulative ERPT during three, six and twelve months are cumulative values of impulse response functions over a respective period. Cumulative ERPT was no longer estimated for 1-month statistically insignificant estimates of ERPT.

The results presented in Table 2 show that in the short-term period ( 1 month) the hypothesis of the absence of exchange rate pass-through to prices is rejected at a $5 \%$ significance level for all combinations of the price indices and variables reflecting the exchange rate. In other words, a significant pass-through effect is observed in the shortterm period. ERPT asymmetry was analyzed by estimating the model (2) which uses variables reflecting appreciation and depreciation of the national currency.

The hypothesis of equal ERPT for different price indices is rejected. The hypothesis of complete ERPT ${ }^{3}$ is rejected for all combinations of price indices and exchange rate indicators. Estimate of ERPT for the consumer price index (CPI) is $4.6 \%$

\footnotetext{
${ }^{3}$ The ERPT is complete if the exchange rate shock pass-through to prices is complete. Within
} the framework of the forequoted hypotheses complete ERPT corresponds to a sum being more than or equal to 1 , of indicators of price level elasticity to exchange rate. 
during the first month. The CPI shows weak response to changes in the exchange rate, changes are estimated about $10.1 \%$ during the first three months, $28.1 \%$ during six months. CPI changes driven by changes in the nominal effective exchange rate of the ruble reach $47.7 \%$ within a year.

Table 2

Estimation results of the ERPT baseline model (price level short-term and cumulative elasticity to exchange rate) and ERPT asymmetry (price level short-term elasticity to exchange rate under appreciation and depreciation of the national currency)

\begin{tabular}{|c|c|c|c|c|c|c|c|c|}
\hline $\begin{array}{l}\text { Model } \\
\text { specific } \\
\text { ation }\end{array}$ & $\begin{array}{c}\text { Depen } \\
\text { dent } \\
\text { variabl } \\
\text { e }\end{array}$ & $\begin{array}{l}\text { Exchan } \\
\text { ge rate } \\
\text { variable }\end{array}$ & $\begin{array}{c}1 \\
\text { Month }\end{array}$ & $\begin{array}{c}3 \\
\text { months }\end{array}$ & $\begin{array}{c}6 \\
\text { Months }\end{array}$ & $\begin{array}{c}12 \\
\text { months }\end{array}$ & $\begin{array}{l}\text { ERPT } \\
\text { under } \\
\text { appreciati } \\
\text { on of the } \\
\text { national } \\
\text { currency }\end{array}$ & $\begin{array}{c}\text { ERPT } \\
\text { under } \\
\text { depreciati } \\
\text { on of the } \\
\text { national } \\
\text { currency }\end{array}$ \\
\hline 1 & $C P I_{t}$ & $N E E R_{t}$ & -0.046 & $-0,101$ & -0.281 & -0.477 & $0.035^{*}$ & -0.062 \\
\hline 2 & $C P I_{t}$ & $U S D E R_{t}$ & -0.028 & -0.109 & -0.375 & -0.855 & $0.0266^{*}$ & -0.069 \\
\hline 3 & $C P I_{t}$ & $E U R E R_{t}$ & -0.029 & -0.063 & -0.206 & -0.570 & $0.041 *$ & -0.056 \\
\hline 4 & $P P I_{t}$ & $N E E R_{t}$ & -0.117 & -0.552 & $-1.579 *$ & $-2.201 *$ & $0.171 *$ & -0.295 \\
\hline 5 & $P P I_{t}$ & $U S D E R_{t}$ & $0.063^{*}$ & & & & 0.315 & $-0.074 *$ \\
\hline 6 & $P P I_{t}$ & $E_{E U R E R_{t}}$ & -0.148 & -0.622 & $-1.775^{*}$ & $-2.569 *$ & $-0.134 *$ & -0.151 \\
\hline 7 & $B C P I_{t}$ & $N E E R_{t}$ & -0.024 & -0.075 & -0.289 & -0.591 & 0.087 & -0.073 \\
\hline 8 & $B C P I_{t}$ & $U S D E R_{t}$ & -0.016 & -0.052 & -0.160 & -0.292 & $0.016^{*}$ & -0.034 \\
\hline 9 & $B C P I_{t}$ & $E U R E R_{t}$ & $-0.008 *$ & & & & 0.064 & -0.050 \\
\hline 10 & $F C P I_{t}$ & $N E E R_{t}$ & $-0.042 *$ & & & & $0.091^{*}$ & -0.105 \\
\hline 11 & $F C P I_{t}$ & $U S D E R_{t}$ & -0.046 & -0.135 & -0.428 & -0.464 & $0.0509 *$ & -0.102 \\
\hline 12 & $F C P I_{t}$ & $E_{E U R E R_{t}}$ & $-0.021 *$ & & & & $0.0286^{*}$ & $-0.045^{*}$ \\
\hline 13 & $N G P I_{t}$ & $N E E R_{t}$ & -0.032 & -0.115 & -0.401 & -0.744 & $0.040 *$ & -0.068 \\
\hline 14 & $N G P I_{t}$ & $U S D E R_{t}$ & $-0.002^{*}$ & & & & 0.035 & -0.027 \\
\hline 15 & $N G P I_{t}$ & EURER $_{t}$ & -0.026 & -0.072 & -0.237 & -0.361 & $0.025^{*}$ & -0.050 \\
\hline
\end{tabular}

Note. The estimates, except those noted with (*) (statistical significance at $10 \%$ is absent), are significant at $5 \%$.

Data source: authors' estimates.

The ERPT estimates obtained for the ruble-dollar and ruble-euro exchange rate are virtually the same in the short-term period (2.8\% and $2.9 \%$ respectively). In time, however, ERPT for the ruble-dollar exchange rate accumulates faster, and eventually a 12 -month ERPT cumulative value is about $85.5 \%$ for this indicator and $57 \%$ for the euro-ruble exchange rate indicator.

The results presented in Table 2 show that the hypothesis of absent ERPT asymmetry is rejected for all of the price indices. In other words, prices (different price 
indices) respond in different ways to appreciation and depreciation of the national currency. It is seen that when the ruble exchange rate depreciates ERPT (nearly for all specifications) is above the level observed throughout the entire considered period. When the ruble appreciates, ERPT estimates have a positive sign and are positive for all combinations of price indices and exchange rate variables. Therefore, the price level grows as the ruble appreciates, but at a slower rate than when it depreciates.

In Table 3 our estimates of the ERPT baseline model are compared with the estimates obtained by other authors. They agree with the results of the papers in which ERPT was studied in countries with low and average level of inflation (e.g., Beirne, Bijsterbosch, 2011). ERPT according to our estimates has declined substantially comparing to the period until 2000.

The results of Zivot-Andrews tests for structural changes demonstrate that changes took place in August 2008 to September 2008 and January 2009 to February 2009 (they generally coincide with the boundaries of the sub-samples into which all observations were broken down).

Table 4 presents the estimation results of all model specifications on the subsamples which in most cases show changes in ERPT, except that a considerable part of its estimates on the first sub-sample (January 2000 to December 2008) is found to be statistically insignificant. It is evident from comparing the estimates obtained for the second sub-sample with the estimates throughout the entire period presented in Table 2 (as well as in Table 4) that the ERPT estimates are higher for the second sub-sample. 
Table 3

Comparing the estimation results of ERPT with the results obtained in other papers

\begin{tabular}{|c|c|c|c|c|c|c|c|c|c|}
\hline \multirow[t]{2}{*}{ Price level indicator } & \multicolumn{2}{|c|}{ Developed countries } & \multicolumn{2}{|c|}{ Developing countries } & \multicolumn{2}{|c|}{ Russia (other papers) } & \multicolumn{3}{|c|}{$\begin{array}{l}\text { Russia (authors' estimates, } \\
\text { period 2000-2012) }\end{array}$} \\
\hline & $\begin{array}{r}\text { Short-term } \\
\text { estimates }\end{array}$ & $\begin{array}{r}\text { Long-term } \\
\text { estimates }\end{array}$ & $\begin{array}{r}\text { Short-term } \\
\text { estimates }\end{array}$ & $\begin{array}{r}\text { Long-term } \\
\text { estimates }\end{array}$ & $\begin{array}{r}\text { Short-term } \\
\text { estimates }\end{array}$ & $\begin{array}{r}\text { Long-term } \\
\text { estimates }\end{array}$ & $\begin{array}{c}1 \\
\text { month }\end{array}$ & $\begin{array}{c}3 \\
\text { months }\end{array}$ & $\begin{array}{c}12 \\
\text { months }\end{array}$ \\
\hline \multirow{4}{*}{$\begin{array}{l}\text { CPI (consumer price } \\
\text { index) }\end{array}$} & $\begin{array}{r}4 \% \text { during } 3 \\
\text { months }\end{array}$ & $\begin{array}{r}14 \% \text { during } 12 \\
\text { months }\end{array}$ & & $\begin{array}{r}20-25 \% \\
\text { during } 6 \\
\text { months } \\
\end{array}$ & $\begin{array}{r}40 \% \text { during one } \\
\text { month }\end{array}$ & $\begin{array}{r}42 \% \text { during } 6 \\
\text { months }\end{array}$ & \multirow[t]{2}{*}{$4.6 \%$} & \multirow[t]{2}{*}{$10.1 \%$} & \multirow[t]{2}{*}{$47.7 \%$} \\
\hline & \multicolumn{2}{|c|}{$\begin{array}{r}\text { Period of 1979-2000 (Chaudri, } \\
\text { Hakura, 2006) } \\
\end{array}$} & \multicolumn{2}{|c|}{ Period of 1995-2008 (Bitans, 2004) } & \multicolumn{2}{|c|}{$\begin{array}{r}\text { Period of 1995-2002 (Dobrynskaya, } \\
\text { Levando, 2005) } \\
\end{array}$} & & & \\
\hline & $\begin{array}{r}1-7 \% \text { during } 12 \\
\text { months }\end{array}$ & $\begin{array}{r}2-13 \% \text { during } \\
24 \text { months }\end{array}$ & $\begin{array}{r}31-48 \% \text { during } \\
12 \text { months }\end{array}$ & $\begin{array}{r}0.35-. .91 \\
\text { during } 24 \\
\text { months } \\
\end{array}$ & $30 \%$ & $50-70 \%$ & & & \\
\hline & \multicolumn{2}{|c|}{$\begin{array}{r}\text { Period of 1975-2004 (Ca'Zorzi et } \\
\text { al., 2007) }\end{array}$} & \multicolumn{2}{|c|}{$\begin{array}{r}\text { Period of 1975-2004 (Ca'Zorzi et } \\
\text { al., 2007) }\end{array}$} & \multicolumn{2}{|c|}{$\begin{array}{r}\text { Period of 1996-2002 (Stavrev, } \\
2003)\end{array}$} & & & \\
\hline \multirow[t]{2}{*}{$\begin{array}{l}\text { PPI (producer price } \\
\text { index) }\end{array}$} & & & $\begin{array}{r}30-58 \% \text { (cross- } \\
\text { country } \\
\text { average) during } \\
3 \text { months }\end{array}$ & $\begin{array}{r}46-93 \% \\
\text { (cross-country } \\
\text { average) } \\
\text { during } 12 \\
\text { months } \\
\end{array}$ & $\begin{array}{r}11 \% \text { during one } \\
\text { month }\end{array}$ & $\begin{array}{r}23 \% \text { during } 6 \\
\text { months }\end{array}$ & \multirow[t]{2}{*}{$11.7 \%$} & \multirow[t]{2}{*}{$55.2 \%$} & \\
\hline & & & \multicolumn{2}{|c|}{ Period 1995-2008 (Bitans, 2004) } & \multicolumn{2}{|c|}{$\begin{array}{r}\text { Period of 1995-2002 (Dobrynskaya, } \\
\text { Levando, 2005) }\end{array}$} & & & \\
\hline \multirow{2}{*}{$\begin{array}{l}\text { Food products price } \\
\text { index }\end{array}$} & & & & & $\begin{array}{r}45 \% \text { during one } \\
\text { month }\end{array}$ & $\begin{array}{r}56 \% \text { during } 6 \\
\text { months }\end{array}$ & \multirow{2}{*}{$4.2 \%$} & & \\
\hline & & & & & Period of 1995-2 & $\begin{array}{l}\text { (Dobrynskaya, } \\
\text { evando, 2005) }\end{array}$ & & & \\
\hline \multirow{3}{*}{$\begin{array}{l}\text { Non-food products } \\
\text { price index }\end{array}$} & & & & & $\begin{array}{r}55 \% \text { during one } \\
\text { month }\end{array}$ & $\begin{array}{r}29 \% \text { during } 6 \\
\text { months } \\
\end{array}$ & \multirow{3}{*}{$3.2 \%$} & \multirow{3}{*}{$11.5 \%$} & \multirow{3}{*}{$74.7 \%$} \\
\hline & & & & & Period of 1995-2 & $\begin{array}{l}\text { (Dobrynskaya, } \\
\text { evando, 2005) }\end{array}$ & & & \\
\hline & & & & & & $\begin{array}{l}\text { of 2003-2005 } \\
\text { ynskaya, 2007) }\end{array}$ & & & \\
\hline
\end{tabular}

Data source: authors' estimates. 
Table 4

Estimation results of the model on subsamples (price level short-term elasticity to exchange rate for each sub-sample)

\begin{tabular}{|l|c|c|r|r|c|}
\hline $\begin{array}{c}\text { Model } \\
\text { specification }\end{array}$ & $\begin{array}{c}\text { Dependent } \\
\text { variable }\end{array}$ & $\begin{array}{c}\text { Exchange } \\
\text { rate variable }\end{array}$ & $\begin{array}{c}\text { ERPT value } \\
\text { Jan. 2000- } \\
\text { Dec. 2008) }\end{array}$ & $\begin{array}{c}\text { ERPT value } \\
\text { (Jan. 2009- } \\
\text { July 2012) }\end{array}$ & $\begin{array}{c}\text { ERPT value } \\
\text { (total period) }\end{array}$ \\
\hline 1 & $C P I_{t}$ & $N E E R_{t}$ & $-0.006^{*}$ & -0.055 & -0.046 \\
\hline 2 & $C P I_{t}$ & $U S D E R_{t}$ & $-0.058^{*}$ & $-0.021^{*}$ & -0.028 \\
\hline 3 & $C P I_{t}$ & $E U R E R_{t}$ & $0.011^{*}$ & -0.058 & -0.029 \\
\hline 4 & $P P I_{t}$ & $N E E R_{t}$ & $-0.078^{*}$ & $0.103^{*}$ & -0.117 \\
\hline 5 & $P P I_{t}$ & $U S D E R_{t}$ & 0.465 & 0.099 & $0.063^{*}$ \\
\hline 6 & $P P I_{t}$ & $E U R E R_{t}$ & -0.098 & $0.046^{*}$ & -0.148 \\
\hline 7 & $B C P I_{t}$ & $N E E R_{t}$ & $0.013^{*}$ & -0.025 & -0.024 \\
\hline 8 & $B C P I_{t}$ & $U S D E R_{t}$ & $-0.009^{*}$ & -0.015 & -0.016 \\
\hline 9 & $B C P I_{t}$ & $E U R E R_{t}$ & $0.014^{*}$ & -0.019 & $-0.008^{*}$ \\
\hline 10 & $F C P I_{t}$ & $N E E R_{t}$ & $0.019^{*}$ & $-0.057^{*}$ & $-0.042^{*}$ \\
\hline 11 & $F C P I_{t}$ & $U S D E R_{t}$ & $-0.042^{*}$ & -0.060 & -0.046 \\
\hline 12 & $F C P I_{t}$ & $E U R E R_{t}$ & $0.0263^{*}$ & -0.063 & -0.021 \\
\hline 13 & $N G P I_{t}$ & $N E E R_{t}$ & $-0.013^{*}$ & $-0.016^{*}$ & -0.032 \\
\hline 14 & $N G P I_{t}$ & $U S D E R_{t}$ & $0.0085^{*}$ & $0.0006^{*}$ & $-0.002^{*}$ \\
\hline 15 & $N G P I_{t}$ & $E U R E R_{t}$ & $-0.006^{*}$ & $-0.015^{*}$ & -0.026 \\
\hline
\end{tabular}

Data source: authors' estimates.

The effect of exchange rate indicator volatility on ERPT is studied by estimating the model (3). The difference between the obtained estimates and the results of the model (1) allows the degree and nature of the exchange rate volatility effect on ERPT to be determined (Table 5). 
Estimation results of the exchange rate volatility impact on ERPT

(price level short-term elasticity to exchange rate)

\begin{tabular}{|l|c|c|c|c|}
\hline $\begin{array}{c}\text { Model } \\
\text { specification }\end{array}$ & $\begin{array}{c}\text { Dependent } \\
\text { variable }\end{array}$ & $\begin{array}{c}\text { Exchange } \\
\text { rate variable }\end{array}$ & Model (3) & Model (1) \\
\hline 1 & $C P I_{t}$ & $N E E R_{t}$ & -0.050 & -0.046 \\
\hline 2 & $C P I_{t}$ & $U S D E R_{t}$ & -0.031 & -0.028 \\
\hline 3 & $C P I_{t}$ & $E U R E R_{t}$ & -0.036 & -0.029 \\
\hline 4 & $P P I_{t}$ & $N E E R_{t}$ & -0.157 & -0.117 \\
\hline 5 & $P P I_{t}$ & $U S D E R_{t}$ & $-0.157^{*}$ & $0.063^{*}$ \\
\hline 6 & $P P I_{t}$ & $E U R E R_{t}$ & -0.163 & -0.148 \\
\hline 7 & $B C P I_{t}$ & $N E E R_{t}$ & -0.021 & -0.024 \\
\hline 8 & $B C P I_{t}$ & $U S D E R_{t}$ & $-0.011^{*}$ & -0.016 \\
\hline 9 & $B C P I_{t}$ & $E U R E R_{t}$ & $-0.011^{*}$ & $-0.008^{*}$ \\
\hline 10 & $F C P I_{t}$ & $N E E R_{t}$ & $-0.033^{*}$ & $-0.042^{*}$ \\
\hline 11 & $F C P I_{t}$ & $U S D E R_{t}$ & $-0.0368^{*}$ & -0.046 \\
\hline 12 & $F C P I_{t}$ & $E U R E R_{t}$ & $-0.037^{*}$ & $-0.021^{*}$ \\
\hline 13 & $N G P I_{t}$ & $N E E R_{t}$ & -0.030 & -0.032 \\
\hline 14 & $N G P I_{t}$ & $U S D E R_{t}$ & -0.005 & $-0.002^{*}$ \\
\hline 15 & $N G P I_{t}$ & $E U R E R_{t}$ & -0.022 & -0.026 \\
\hline
\end{tabular}

Data source: authors' estimates.

Some coefficient estimates are statistically insignificant. However, the major part of statistically significant estimates see a slight increase in ERPT absolute value vs. the estimates obtained for the model (1). Therefore, the exchange rate volatility gives rise to reduction of ERPT. This presumably reflects the effect of expectations on its magnitude: economic agents revise prices less frequently due to a high volatility of exchange rate. Additionally, the effect of multidirectional exchange rate shocks can be reciprocally offset, because a substantial number of such shocks may, amid high volatility, occur within a short period.

$* * *$

The effect of the national currency exchange rate changes on domestic prices should be estimated to ensure that the central bank is able to conduct an efficient monetary and foreign exchange policy. Analysis of the theoretical and empirical literature dedicated to studying the pass-through effect allowed a ERPT estimation 
methodology to be developed in Russia and the hypotheses about ERPT scale and structural properties tested.

The baseline estimates obtained for the period of January 2000 to July 2012 show a statistically significant ERPT in the short and medium-term period. Furthermore, the pass-through effect is incomplete in both periods.

A short-term ERPT (1-month period) is statistically significant for all of the price indices under review, averaging 3-5\% for CPI, 3-12\% for PPI, 1-2\% for BCPI, 2-3\% for the non-food products price index, and about $5 \%$ for the food products price index. Note that the dollar exchange rate pass-through to consumer prices tends to be higher than the euro one. This is presumably associated with the fact that the US dollar traditionally plays the role of the principal foreign currency in the Russian Federation, whilst most of imported consumer goods are denominated in euro.

The obtained estimates show price level's minor adaptation to exchange rate fluctuations in the first month, while the major part of changes occur in the following 6-12 months. These results are slightly higher in absolute terms than the results obtained for developed countries with low-level inflation, where ERPT averages 4-5\% quarterly and 14-15\% annually. The estimates of ERPT obtained in Russia are in line to a greater extent with those obtained for developing countries. Our results agree in general with the conclusions of other authors. The ERPT downtrend detected in the recent papers also continues to persist in the period (2000-2012) covered by our study.

The results of the estimates show ERPT asymmetry (diverse nature of the effect of appreciation and depreciation of the national currency on price level) for all price indices. A depreciation of the national currency leads to growth in prices, whilst its appreciation triggers no fall of prices. This fact should be considered in conducting monetary policy aimed at flattening volatility of the ruble exchange rate. Other papers show ERPT asymmetry in Russia as well. Estimation of an impact of the exchange rate volatility on ERPT shows that increase in the former makes the latter slide down a bit, which is presumably explained by the effect of economic agents' expectations, as well as reciprocal offset of shocks. 
Analysis of structural changes in ERPT shows significant differences for the two sub-periods under review (January 2000 to December 2008, and January 2009 to July 2012). According to our estimates ERPT value increased in absolute terms in the second sub-period against the first one. However, no conclusion can be drawn about cause-effect relations between the detected structural changes in ERPT and changes in the Central Bank's monetary policy, because the second sub-period is fairly short; additionally, the global economic crisis might have a strong impact on the estimates. The effect of the transition to an inflation targeting policy on ERPT specific features cannot be reliably estimated until the global crisis effects have worn out completely and the Central Bank finished the transition to the policy, which is to be done by 2015 . 


\section{REFERENCES}

Dementiev A., Bessonov I. (2012). Construction of Core Inflation Index for Inflation Targeting in Russia // Moscow: HSE Publ.

Dobrynskaya V. (2007). Exchange Rate Pass-through and monetary policy in Russia: what changed after 1998 crisis? // HSE Economic Journal. No 2. pp. 213-233

Drobyshevskiy S., Sinelnikov S., Trunin P. (2011). G20 Anti-crisis Economic Policy Coordination Decisions and Russia’s Experience // Ekonomicheskoe Vozrozhdenie Rossii. Vol. 18, No 5. P. $29-44$.

Salitsky I. (2010). Exchange Rate Pass-through into Import Prices in Russian Federation // Ekonomicheskaya Politika. No 6. pp 176-195.

Ulyukaev A., Drobyshevsky S., Trunin P. (2008) Prospects of the Initiation of Inflation Targeting in RF // Voprosy Ekonomiki. 2008, No 1, P. 46-57.

Bacchetta P., Wincoop E. (2003). Why Do Consumer Prices React Less than Import Prices to Exchange Rates? // Journal of the European Economic Association. Vol. 1, No 2-3. P. 662 670.

Bailliu J., Fujii E. (2004). Exchange Rate Pass-through and the Inflation Environment in Industrialized Countries: An Empirical Investigation // Bank of Canada Working Paper. No 2004-21.

Ball L., Mankiw G. N., Romer D. (1988). The New Keynesian Economics and the Output-Inflation Trade-off // Brookings Papers on Economic Activity. Vol. 1988, No 1. P. 1-82.

Beirne J., Bijsterbosch M. (2011). Exchange Rate Pass-through in Central and Eastern European EU Member States // Journal of Policy Modeling. Vol. 33, No 2. P. 241-254.

Bitans M. (2004). Pass-through of Exchange Rates to Domestic Prices in East European Countries and the Role of Economic Eenvironment // Bank of Latvia Working Paper. No 4/2004.

Calvo G. A., Reinhart C. M. (2002). Fear of Floating // The Quarterly Journal of Economics. Vol. 117, No 2. P. 379-408.

Ca'Zorzi M., Hahn E., Sánchez M. (2007). Exchange Rate Pass-through in Emerging Markets // ECB Working Paper. No 739.

Choudhri E. U., Hakura D. S. (2006). Exchange Rate Pass-through to Domestic Prices: Does the Inflationary Environment Matter? //Journal of International Money and Finance. Vol. 25, No 4. P. 614-639.

Cozmânca B. O., Manea F. (2010). Asymmetries in the Exchange Rate Pass-through into Romanian Price Indices // Romanian Journal of Economic Forecasting. No 1. P. 21-44. 
Devereux M. B., Engel C., Storgaard P. E. (2004). Endogenous Exchange Rate Pass-through When Nominal Prices Are Set in Advance // Journal of International Economics. Vol. 63, No 2. P. 263-291.

Dobrynskaya V. V., Levando D. V. (2005). A Study of Exchange Rate Pass-through Effect in Russia // SU-HSE. International College of Economics and Finance Working Paper. No WP9/2005/02.

Dolado J. J., Maria-Dolores R., Naveira M. (2005). Are Monetary-Policy Reaction Functions Asymmetric? The Role of Nonlinearity in the Phillips Curve // European Economic Review. Vol. 49, No 2. P. 485-503.

Engel C., Rogers J. (1998). Regional Patterns in the Law of One Price: The Roles of Geography versus Currencies // The Regionalization of the World Economy. University of Chicago Press.

Engel C. (2002). The Responsiveness of Consumer Prices to Exchange Rates and the Implications for Exchange-Rate Policy: A Survey of a Few Recent New Open-Economy // NBER Working Paper. No w8725.

Flodén M., Wilander F. (2006). State Dependent Pricing, Invoicing Currency, and Exchange Rate Pass-through // Journal of International Economics. Vol. 70, No 1. P. 178-196.

Froot K. A., Klemperer P. D. (1989). Exchange Rate Pass-through When Market Share Matters // The American Economic Review. Vol. 79, No 4. P. 637-654.

Gagnon J. E., Ihrig J. (2004). Monetary Policy and Exchange Rate Pass-through // International Journal of Finance \& Economics. Vol. 9, No 4. P. 315-338.

Goldberg P. K., Knetter M. M. (1996). Goods Prices and Exchange Rates: What Have We Learned? // NBER Working Paper. No w5862.

Gopinath G., Itskhoki O., Rigobon R. (2007). Currency Choice and Exchange Rate Pass-through // NBER Working Paper. No w13432.

Knetter M. M. (1994). Is Export Price Adjustment Asymmetric? Evaluating the Market Share and Marketing Bottlenecks Hypotheses // Journal of International Money and Finance. Vol. 13, No 1. P. 55-70.

Mann C. L. (1986). Prices, Profit Margins, and Exchange Rates // Federal Reserve Bulletin. Vol. 72. P. 366-379.

McCallum B., Nelson E. (2000). Monetary Policy for an Open Economy: An Alternative Framework with Optimizing Agents and Sticky Prices // Oxford Review of Economic Policy. Vol. 16, No 4. P. 74-91.

McCarthy J. (2000). Pass-through of Exchange Rates and Import Prices to Domestic Inflation in Some Industrialized Economies // FRB of New York Staff Report. 
Obstfeld M., Rogoff K. (2000). New Directions for Stochastic Open Economy Models // Journal of International Economics. Vol. 50, No 1. P. 117-153.

Obstfeld M., Rogoff K. (2001). The Six Major Puzzles in International Macroeconomics: Is There a Common Cause? // NBER Macroeconomics Annual 2000. Vol. 15. MIT Press. P. 339-412.

Obstfeld M. (2001). International Macroeconomics: Beyond the Mundell-Fleming Model // NBER Working Paper. No w8369.

Ohno K. (1990). Exchange rate fluctuations, pass-through, and market share // Staff PapersInternational Monetary Fund. P. 294-310.

Oomes N., Ohnsorge F. (2005). Money Demand and Inflation in Dollarized Economies: The case of Russia // Journal of Comparative Economics. Vol. 33, No 3. P. 462-483.

Phillips R. W. (1988). The Pass-through of Exchange Rate Changes to Prices of Imported Manufacturers // Australian National University. Centre for Economic Policy Research. No 197.

Stavrev E. (2003). The Pass-through from the Nominal Exchange Rate to Inflation // Russian Federation: Selected Issues. IMF Country Report. No 03/146.

Takhtamanova Y. F. (2010). Understanding Changes in Exchange Rate Pass-through // Journal of Macroeconomics. Vol. 32, No 4. P. 1118-1130.

Taylor J. B. (2000). Low Inflation, Pass-through, and the Pricing Power of Firms // European Economic Review. Vol. 44, No 7. P. 1389-1408.

Zivot E., Andrews D. W. K. (2002). Further Evidence on the Great Crash, the Oil-Price Shock, and the Unit-Root Hypothesis // Journal of Business \& Economic Statistics. Vol. 20, No 1. P. 2544. 